\title{
Effervescent Rosela Ungu Mencegah Penurunan Nilai SOD dan Mencegah Nekrosis Hepar Tikus Wistar yang Diberi Minyak Jelantah
}

\section{Purple Rosella Effervescent Prevents the Decrease of SOD Value and Prevents Liver Necrosis of Wistar which Exposed by Waste Cooking Oil}

\author{
Hafiz Iqbal $M^{1}$, Arya Ulilalbab², Anugerah Dani $P^{3}$, Teti Estiasih ${ }^{1}$ \\ ${ }^{1}$ Program Studi Ilmu dan Teknologi Pangan Universitas Brawijaya Malang \\ ${ }^{2}$ Program Studi Magister IImu Kesehatan Masyarakat Universitas Airlangga Surabaya \\ ${ }^{3}$ Double Degree Jurusan Teknologi Hasil Pertanian Universitas Brawijaya Malang
}

\begin{abstract}
ABSTRAK
Effervescent rosela ungu merupakan salah satu bentuk diversifikasi pangan lokal yang tinggi antioksidan. Antioksidan memiliki efek mencegah reaksi oksidasi sehingga tidak sampai terjadi stres oksidatif. Tujuan penelitian ini yaitu untuk mengetahui efek antioksidan effervescent rosella ungu dalam mencegah penurunan SOD dan mencegah kerusakan sel hepar tikus wistar. Penelitian ini disusun menggunakan Post-test Only Control Group Design dengan Rancangan Acak lengkap (RAL), menggunakan tikus wistar jantan sebanyak 16 ekor dan lama perlakuan selama 4 minggu. Terdapat 4 kelompok, kontrol negatif (pakan standar $+3 \mathrm{ml}$ aquadest), kontrol positif (pakan standar + minyak jelantah $1 \mathrm{ml}$ $118 \mathrm{mek} / \mathrm{kg}+2 \mathrm{ml}$ aquadest), perlakuan dosis I (pakan standar + minyak jelantah $1 \mathrm{ml} 118 \mathrm{mek} / \mathrm{kg}+$ effervescent rosela ungu $3 \mathrm{~g} / 2 \mathrm{ml}$ ), dan perlakuan dosis II (pakan standar + minyak jelantah $1 \mathrm{ml} 118 \mathrm{mek} / \mathrm{kg}+$ effervescent rosella ungu $6 \mathrm{~g} / 2$ $\mathrm{ml}$. Hasil pengamatan dianalisa dengan ANOVA dan dilanjutkan uji BNT dengan taraf $5 \%$. Hasil penelitian menunjukkan perlakuan uji in vivo berpengaruh nyata $(\alpha=0,05)$ terhadap nilai SOD serum. Pengamatan sel hepar tikus wistar secara histopatologi menunjukkan kelompok perlakuan dosis I maupun dosis II mampu mencegah terjadinya stres oksidatif dengan indikasi sangat sedikit sel hepar yang mengalami nekrosis.
\end{abstract}

Kata Kunci: Antioksidan, effervescent, minyak jelantah, SOD, nekrosis hepar, rosela ungu

\section{ABSTRACT}

Purple rosella effervescent is one diversification forms of local food which containing high antioxidant. Antioxidant has an effect to prevent oxidation reaction, thus it can prevent oxidative stress. The objective of this research is to find out antioxidant effect of purple rosella effervescent in preventing the decrease of SOD value and in preventing the damage of hepar's cell of wistar. This research was composed by using Post-test Only Control Group Design with Complete Randomized Design, using 16 male wistar rats, and 4 week treatment time. There were 4 groups, namely negative control (standard food $+3 \mathrm{ml}$ distilled water), positive control (standard food $+1 \mathrm{ml} \mathrm{118mek/kg} \mathrm{waste} \mathrm{cooking} \mathrm{oil}+2 \mathrm{ml}$ distilled water), dose I treatment (standard food $+1 \mathrm{ml} 118 \mathrm{mek} / \mathrm{kg}$ waste cooking oil $+3 \mathrm{~g} / 2 \mathrm{ml}$ purple rosella effervescent), and dose II treatment (standard food $+1 \mathrm{ml} 118 \mathrm{mek} / \mathrm{kg}$ waste cooking oil $+6 \mathrm{~g} / 2 \mathrm{ml}$ purple rosella effervescent). The result of the observation was analysed by using ANOVA and continued by BNT test with $5 \%$ degree. The result shows that the treatment of in vivo test has significant effect $(\alpha=0,05)$ towards SOD serum value. The histopathologically observation of hepar's cell of wistar shows both treatment groups of dose I and dose II can prevent oxidative stress with little indication of hepar cells experiencing necrosis.

Keywords: Antioxidant, effervescent, liver necrosis, purple rosella, SOD, waste cooking oil

Jurnal Kedokteran Brawijaya, Vol. 28, No. 2, Agustus 2014; Korespondensi: Hafiz labal M. Program Studi Ilmu dan Teknologi Pangan Universitas Brawijaya Malang, Jl. Veteran, Malang Jawa Timur 65145 Tel. (0341) 573358Email:maulana.hafiz88@gmail.com 


\section{PENDAHULUAN}

Penyakit degeneratif seperti kanker, asteroklerosis, stroke, hiperlipidemia, serta perlemakan hati merupakan beberapa penyakit yang berkaitan dengan aktivitas radikal bebas dan konsumsi makanan yang digoreng dengan minyak hasil penggorengan berulang (gorengan). Pada minyak jelantah banyak terkandung minyak jenuh dan radikal bebas hasil peroksidasi lemak. Radikal bebas tersebut sebenarnya dapat dihambat dengan antioksidan (1). Pada tubuh dalam kondisi dan aktivitas normal serta asupan makanan yang seimbang tidak perlu tambahan suplemen antioksidan. Dalam keadaan tertentu seperti meningkatnya usia, sakit, lingkungan tidak sehat dan tercemar oleh berbagai polusi, perokok berat atau pada orang yang sering mengkonsumsi gorengan, maka perlu mengkonsumsi suplemen antioksidan.

Makanan tinggi antosianin akhir-akhir ini menjadi lebih populer. Studi epidemiologi menunjukkan bahwa konsumsi antosianin menurunkan risiko penyakit jantung, diabetes, arthritis dan kanker, karena antioksidan bersifat anti inflamasi $(2,3)$. Dianjurkan untuk mengkonsumsi soft drink yang mengandung pigmen antosianin, karena pada dosis rendah yaitu sebesar $50 \mathrm{mg} / \mathrm{kg}$ secara efektif menunjukkan aktivitas antioksidan dalam melawan hipertensi dan gangguan hati. Antosianin merupakan salah satu pigmen alami yang larut air dan tergolong dalam senyawa flavonoid dan merupakan glikosida dari antioksidan yang tersusun atas inti gugus (nukleus) 2phenol benzopyrillium (flavium). Biasanya warna merah, ungu, dan biru yang menarik terdapat pada bunga, buah dan sayuran (4).

Effervescent rosela ungu adalah salah satu bentuk diversifikasi pangan yang memanfaatkan rosela ungu sebagai bahan baku guna meningkatkan nilai jualnya. Effervescent dibuat dengan cara mengeringkan campuran berupa natrium bikarbonat, asam sitrat, senyawa aktif dan bahan tambahan lainnya seperti sukrosa dan bahan pengisi (5). Pelarutan effervescent menimbulkan reaksi spontan antara senyawa asam dan senyawa karbonat yang menghasilkan gas $\mathrm{CO}_{2}$ yang memiliki efek sparkling atau rasa seperti soda (6).

Tubuh memiliki sistem antioksidan primer berupa Superoxide dismutase (SOD). Kekurangan SOD memberikan konsekuensi atas meningkatnya Malondialdehyde (MDA) sebagai indikator adanya radikal bebas yang dapat menyebabkan kondisi stres oksidatif pada sel (7). Antioksidan primer yang dihasilkan oleh tubuh tidak cukup untuk melawan radikal bebas yang ada di dalam tubuh, sehingga diperlukan asupan antioksidan dari luar tubuh seperti antosianin (8). Antioksidan di dalam tubuh tidak mencukupi dalam melawan radikal bebas dapat disebabkan diantaranya oleh faktor lingkungan seperti adanya polusi asap rokok dan kebiasaan konsumsi makanan gorengan. Diharapkan effervescent rosela ungu tinggi antioksidan bisa sebagai alternatif sebagai suplemen antioksidan.

\section{METODE}

\section{Desain}

Penelitian ini merupakan experimental laboratorium dilakukan secara post test control group design dengan Rancangan Acak Lengkap (RAL). Penelitian ini terbagi menjadi 4 kelompok, tiap kelompok terdapat 4 ekor tikus wistar. Pemberian pakan dilakukan secara ad libitum. Pada kelompok perlakuan, dilakukan diberikan $1 \mathrm{ml}$ minyak jelantah $118 \mathrm{mek} / \mathrm{kg}$ melalui sonde selama sehari dan 8 jam kemudian diberikan $2 \mathrm{ml}$ larutan effervescent melalui sonde sesuai dosis.

Kelompok I=kontrol negatif (tikus hanya diberi pakan standard+sonde aquadest $3 \mathrm{ml}$ ), kelompok II=kontrol positif (tikus diberi pakan standar+sonde minyak jelantah $118 \mathrm{mek} / \mathrm{kg} 1 \mathrm{ml}+$ sonde $2 \mathrm{ml}$ aquadest), kelompok $\mathrm{II}=$ perlakuan dosis I (tikus diberi pakan standard+sonde minyak jelantah $118 \mathrm{mek} / \mathrm{kg} 1 \mathrm{ml}+3$ gr effervescent dalam $2 \mathrm{ml}$ aquadest), kelompok IV=perlakuan dosis II (tikus diberi pakan standard+sonde minyak jelantah $118 \mathrm{mek} / \mathrm{kg}$ $1 \mathrm{ml}+6$ gr effervescent dalam $2 \mathrm{ml}$ aquadest).

Pengamatan yang dilakukan pada effervescent rosela ungu meliputi analisa aktivitas antioksidan dan kadar antosianin. Untuk uji in vivo dilakukan analisa SOD serum dan kemudian dianalisa menggunkan ANOVA, dilanjutkan dengan uji lanjut BNT (Beda Nyata Terkecil) apabila terdapat perbedaan. Dilakukan pengamatan histopatologi sel hepar secara deskriptif.

\section{Bahan}

Bahan yang digunakan yaitu rosela ungu yang diperoleh dari Kecamatan Semen Kabupaten Kediri. Bahan lain yang digunakan meliputi dekstrin, asam sitrat, natrium bikarbonat, gula pasir, kertas saring, indikator PP, aquadest, $\mathrm{NaOH}$, Nelson arsenomolibdat, buffer $\mathrm{KCl}$ dan $\mathrm{HCl}$ 0,2 M untuk buffer $\mathrm{pH} 1$, asam asetat (pa) untuk buffer $\mathrm{pH} 4,5$, etanol $95 \%$ (pa), $\mathrm{HCl} 1 \%$, methanol $\mathrm{Na}_{2} \mathrm{CO}_{3} 2 \%$, indikator phenolphthalein, $\mathrm{NaCl}$, ammonium tiosianat, dan kertas saring Whatman No. 1, asam galat, EDTA, buffer phosfat, NBT, TCA $100 \%, \mathrm{HCl} 1 \mathrm{~N}, \mathrm{Na}-\mathrm{Thio} 1 \%$, larutan 1,1diphenil-2-pieryllhydrazil (DPPH) 0,2 M, buffer Neutral Formalin (BNF), parafin, dan pewarnaan sel HematoksilinEosin (HE). Hewan coba yang digunakan adalah tikus wistar jantan usia 100-120 hari dengan berat badan antara 150200gr. Sebagai sumber makanan dengan potensi stres oksidatif digunakan minyak jelantah dari pedagang lalapan di kota Malang. Pakan tikus memakai pakan produksi PT. JAPFA Comfeed Indonesia.

\section{Ekstraksi Filtrat Rosela Ungu}

Untuk pembuatan ekstrak filtrate rosela ungu air $400 \mathrm{ml}$ didihkan sampai mendidih. Dilakukan sortasi kelopak bunga dan kemudian dibersihkan dari kotoran. Sebanyak 50gr kelopak yang telah diberisihkan ditempat dalam wadah kemudian dituangi dengan air panas dengan suhu $80^{\circ} \mathrm{C}$. Kemudian dilakukan ekstraksi selama 30 menit dalam wadah tertutup. Ekstraksi bertujuan supaya zat kimia dalam rosela keluar secara optimal. Seduhan tersebut disaring dengan kain saring lalu diletakkan ke dalam beaker glass. Hasil seduhan disebut filtrat rosela ungu. Filtrat rosela ungu selanjutnya dianalisa aktivitas antioksidan dan kadar antosianin.

\section{Pembuatan Effervescent Rosela Ungu}

Filtrat rosela ungu ditambah dengan dekstrin 50\% (b/v). Campuran dituangkan ke loyang dan dikeringkan dengan pengering vakum selama $8 \mathrm{jam}$ pada suhu $60^{\circ} \mathrm{C}$. Hasil pengeringan dihaluskan sehingga dihasilkan serbuk ekstrak rosela ungu. Serbuk dicampuran sukrosa $75 \%$ (b/b), asam sitrat dan natrium bikarbonat sejumlah $16 \%$ (b/v) lalu dihomogenisasi. Effervescent rosela ungu yang terbentuk diayak dengan ayakan 60 mesh supaya didapatkan serbuk yang homogen dan memudahkan jika melakukan pembuatan tablet. Setelah itu dilakukan 
analisa aktivitas antioksidan dan kadar antosianin.

\section{Tahap Uji In Vivo}

Proses pertama yaitu adaptasi selama 1 minggu, setelah itu dilakukan proses perlakuan selama 4 minggu. Uji in vivo dilakukan menurut kelompok perlakuan berdasarkan rancangan percobaan. Pada akhir penelitian dilakukan euthanasi menggunakan chloroform untuk membius tikus dan selanjutnya dilakukan nekropsi (pembedahan) untuk mengambil darah dari jantung serta mengambil hepar. Darah yang diambil dilakukan pengujian bio-assay terhadap profil serum darah tikus untuk menentukan nilai SOD. Sedangkan organ hepar dilakukan mikroteknik dan pewarnaan sel hepar dengan HE (Hematoksilin-Eosin) untuk didapat preparat slide sel hepar untuk diamati gambaran histopatologi selnya.

\section{HASIL}

\section{Karakteristik Kimia Filtrat dan Effervescent Rosela Ungu}

Hasil analisa pada Tabel 1 diketahui nilai total antosianin filtrat rosela ungu $582,37 \mathrm{ppm}$. Nilai total antosianin effervescent rosela ungu 225,98 ppm. Aktivitas antioksidan filtrat rosela ungu $35,04 \%$ dan aktivitas antioksidan effervescent rosela ungu $26,18 \%$.

Tabel 1. Data hasil analisa tiap $1 \mathrm{gr}$ effervescent rosela ungu

\begin{tabular}{lccr}
\hline \multicolumn{1}{c}{ Parameter } & $\begin{array}{c}\text { Analisa } \\
\text { Effervescent }\end{array}$ & $\begin{array}{c}\text { Analisa } \\
\text { Filtrat }\end{array}$ & Filtrat (9) \\
\hline Total Antosianin (ppm) & 225,98 & 582,37 & 611 \\
Aktivitas antioksidan (\%) & 26,18 & 35,04 & 63,92 \\
\hline
\end{tabular}

Hasil uji statistik ragam (ANOVA) menunjukkan bahwa jenis kelompok perlakuan pada uji in vivo memberikan pengaruh nyata $(\alpha=0,005)$ terhadap nilai SOD, sehingga perlu dilakukan uji lanjut BNT untuk melihat kelompok perlakuan yang berbeda. Tabel 2 berikut menunjukkan rerata hasil uji BNT.

Tabel 2. Rerata nilai SOD pada berbagai kelompok perlakuan

\begin{tabular}{lc}
\hline Jenis Kelompok & Rerata Nilai SOD \\
\hline Kontrol Negatif & $65,13 \mathrm{c}$ \\
Kontrol Positif & $21,38 \mathrm{a}$ \\
Dosis 1 & $37,72 \mathrm{~b}$ \\
Dosis 2 & $43,86 \mathrm{~b}$ \\
BNT 5\% & 13,047 \\
\hline
\end{tabular}

Keterangan: rerata yang didampingi huruf yang sama menyatakan tidak berbeda nyata

Nilai SOD paling rendah ada pada kelompok kontrol positif. Pada kelompok dosis II mempunyai nilai SOD lebih tinggi dibandingkan kelompok kontrol positif dan kelompok dosis I. Nilai SOD paling tinggi terdapat pada kelompok kontrol negatif.
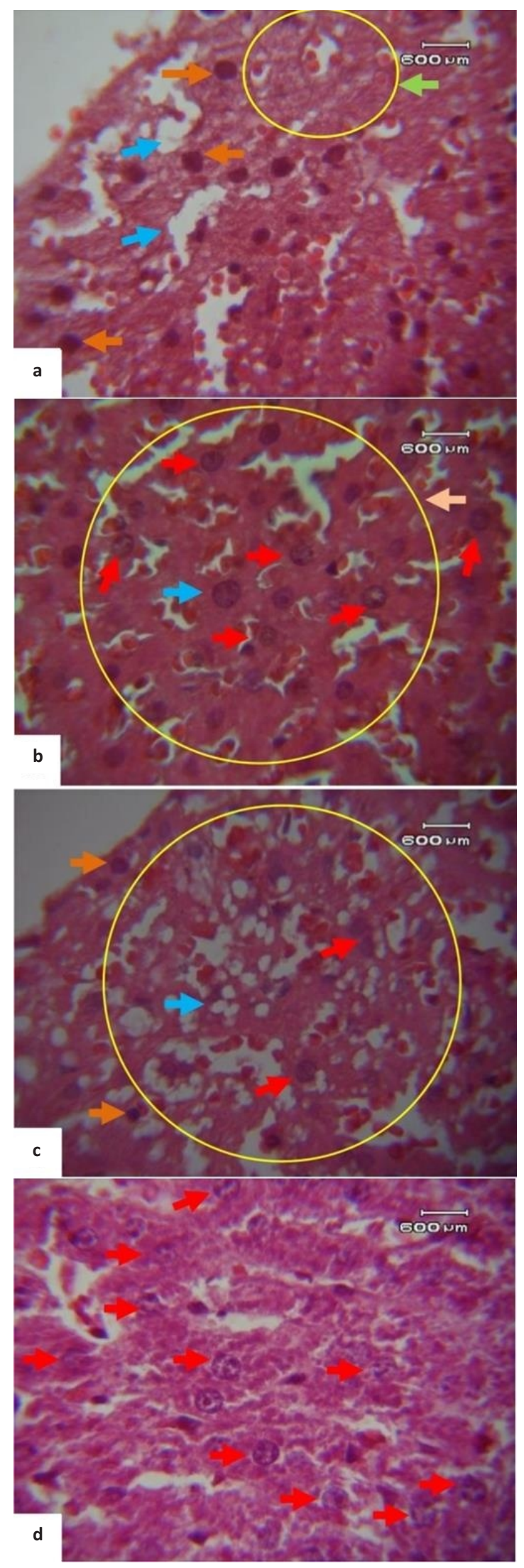

Gambar 1. Gambar histopatologi sel hepar tikus perbesaran 1000x dengan pewarnaan $\mathrm{HE}$

Keterangan:

a) kelompok kontrol positif menunjukkan ciri-ciri sel nekrosis yang bersifat irreversibel; b). kelompok kontrol negatif menunjukkan ciri-ciri sel normal; c). kelompok dosis I menunjukkan ciri-ciri tingkat kerusakan sedang (bersifat reversibel) pada sel; d). kelompok dosis II menunjukkan ciri-ciri tingkat kerusakan ringan (reversibel) pada sel 
Keterangan (Lanjutan):

Karyolisis (inti sel mengalami lisis kemudian menghilang). Mula mula inti sel menjadi sangat pucat dikarenakan rusaknya kromatin yang dimungkinkan akibat adanya pergerakan dari DNAase dan RNAase. Lama kelamaan inti akan mengalami lisis dan menghilang.

Hydrophic degeneration akibat adanya influks air ke dalam sel. Influks air ke dalam sel diakibatkan karena meningkatnya tekanan osmotik di dalam sel. Hal ini dikarenakan adanya injury yang dialami oleh sel. Injury bisa disebabkan oleh toksin berupa radikal bebas.

Piknosis. Di awal proses kemunduran sel terjadi piknosis berupa inti sel yang tampak memadat akibat kromatin yang mengkerut, berbentuk bulat, gelap, dan homogen.

Inti sel dengan tipe oped face nucleus. Inti tampak transparan sehingga terlihat nukleolus serta kromatin penyusun RNA di dalam inti sel dengan jelas.

Area yang menunjukkan ciri - ciri struktur morfologi sel hepar normal. Inti sel tampak berbentuk tidak teratur, tidak gelap, dan cenderung transparan (open face nucleus). Selain itu pulasan warna HE akan tampak jelas dan tidak pucat. Hal ini menandakan sel normal dan cenderung sehat

Secara umum pada Gambar 1a menunjukkan bahwa pada kontrol positif mengalami kondisi stres oksidatif. Hal ini ditunjukkan dengan banyaknya sel yang mengalami irreversible injury dan berujung pada kematian sel atau biasa disebut nekrosis. Kondisi stres oksidatif pada kelompok kontrol positif dikarenakan adanya asupan $1 \mathrm{ml}$ minyak jelantah dengan nilai peroksida sejumlah $118 \mathrm{mek} / \mathrm{kg}$ sebagai indikasi kadar radikal bebas yang terkandung di dalamnya. Gambar histopatologi sel hepar kelompok kontrol negatif pada gambar $1 \mathrm{~b}$ menunjukkan ciri-ciri sel normal. Hanya terlihat penampakan sel dengan ciri open face nukleus dan fenomena hydrophic degeneration dalam jumlah yang sangat sedikit.

Secara umum kelompok perlakuan baik pada dosis I dan dosis II pada Gambar 1c dan 1d, jarang ditemukan perubahan inti sel sebagai indikator sel nekrosis. Hanya tampak sel yang mengalami reversible injury berupa hydrophic degeneration saja yang mendominasi. Jika dibandingkan dengan kelompok kontrol positif, kelompok perlakuan baik pada pemberian effervescent rosela ungu dosis I maupun dosis II, tidak menunjukkan kerusakan sel yang parah atau nekrosis (ditandai dengan adanya perubahan pada inti sel) yang diakibatkan oleh stres oksidatif. Perbedaan ini dikarenakan adanya tambahan asupan antioksidan berupa effervescent rosela ungu baik pada dosis I dan dosis II pada kelompok perlakuan yang mampu meningkatkan nilai SOD sebagai antioksidan intraseluler.

\section{DISKUSI}

Pada penelitian ini, didapatkan nilai total antosianin kelopak rosela ungu sebesar 582,37 ppm. Sebaliknya dari literatur disebutkan bahwa besarnya antosianin pada kelopak rosela adalah 611 ppm (9). Hal ini dikarenakan pengaruh pemanasan pada proses pengeringan menyebabkan rusaknya komponen dan penurunan stabilitas antosianin bahan sehingga kadar antosianin turun. Penurunan antosianin akibat proses pengolahan menjadi effervescent rosela ungu tersebut mampu diminimalisir dengan adanya penambahan bahan pengisi berupa dekstrin. Molekul dekstrin stabil terhadap panas dan oksidasi sehingga dapat digunakan untuk melindungi senyawa volatil (10).

Hasil analisa aktivitas antioksidan effervescent rosela ungu (Tabel 1) sebesar 26,18\%, lebih rendah bila dibandingkan dengan aktivitas antioksidan filtrat rosela ungu yaitu sebesar $35,04 \%$. Hal ini dikarenakan proses pengeringan menyebabkan penurunan kestabilan antosianin sehingga aktivitas antioksidan effervescent rosela ungu ikut menurun. Degradasi antosianin yang merupakan sumber antioksidan menyebabkan penurunan aktivitas antioksidan produk (11).

Hasil analisa bilangan peroksida terhadap minyak jelantah menunjukkan angka sebesar $118 \mathrm{mek} / \mathrm{kg}$. Berdasarkan angka bilangan peroksida, diduga minyak jelantah yang digunakan pedagang lalapan tersebut telah digunakan berulang kali. Semakin tinggi frekuensi dan ulangan penggorengan maka semakin besar pula bilangan peroksida yang dihasilkan (12). Bilangan peroksida dapat digunakan sebagai petunjuk adanya kerusakan oksidatif pada minyak atau lemak serta menunjukkan sejumlah radikal bebas yang terukur sebagai peroksida yang bersifat toksin pada tubuh. Nilai batas aman bilangan peroksida (meq/kg) menurut Codex Alimentarius Committee FAO/ WHO dan European Union (E 322) yaitu $<10$, sedangkan menurut Food Chemical Codex sebesar $<100$.

Pengukuran nilai SOD (Tabel 2) dalam penelitian ini menggunakan prinsip yaitu reaksi antara xanthine dan xanthine oksidase dengan EDTA (Ethylene Diamine Tetraacetic Acid) sebagai donor anion menghasilkan radikal superoksida. Radikal superoksida akan mereduksi NBT (Nitro Blue Tetrazolium) menjadi formazan yang berwarna ungu. Satu unit aktivitas SOD menunjukkan sejumlah enzim yang dibutuhkan dalam menghambat reduksi NBT melalui reaksinya dengan radikal superoksida yang menghasilkan $\mathrm{O}_{2}$ dan $\mathrm{H}_{2} \mathrm{O}_{2}$ (13). Tujuan yang ingin dicapai dalam penelitian ini adalah untuk mengetahui bahwa pemberian effervescent rosela ungu dengan dosis yang telah ditentukan mampu memberikan efek antioksidan dalam mengatasi stres oksidatif pada tikus yang diinduksi dengan minyak jelantah. Pada kelompok perlakuan dosis I dan dosis II, nilai SOD sedikit mengalami pengurangan dibandingkan kelompok kontrol positif yang mengalami banyak pengurangan, acuan nilai SOD yang normal ada pada kelompok kontrol negatif.

Hasil uji lanjut BNT (Tabel 2) menunjukkan bahwa kelompok kontrol negatif berbeda dengan kelompok kontrol positif. Hal ini dikarenakan kelompok kontrol negatif merupakan kelompok kontrol tikus yang hanya diberi perlakuan pakan standar saja (normal) tanpa penambahan minyak jelantah maupun effervescent rosela ungu sehingga mengakibatkan nilai SOD pada serum tikus masih normal. Kelompok kontrol positif merupakan kelompok yang dikondisikan mengalami stres oksidatif dengan perlakuan pakan standar disertai penyondean minyak jelantah sebanyak $1 \mathrm{ml} /$ hari yang mempunyai nilai bilangan peroksida yang tinggi yaitu sebesar $118 \mathrm{mek} / \mathrm{kg}$. Nilai SOD pada kelompok ini mengalami penurunan jika dibandingkan dengan kelompok kontrol negatif, sehingga mengindikasikan telah terjadi stres oksidatif. Tidak adanya asupan antioksidan menyebabkan radikal bebas dalam darah mengalami peningkatan yang ditandai dengan penurunan nilai SOD.

Pada perlakuan baik penambahan effervescent rosela 
ungu dosis I maupun dosis II berbeda nyata dengan kelompok kontrol positif dan kelompok kontrol negatif. Penambahan effervescent rosela ungu dosis I (3g/ekor) tidak berbeda nyata dengan kelompok penambahan effervescent rosela ungu dosis II (6g/ekor). Diketahui bahwa rerata nilai SOD pada kelompok kontrol negatif adalah 65,13 unit/ml, kelompok kontrol positif adalah 21,38 unit/ml, kelompok perlakuan dosis I adalah 37,72 unit/ml, dan kelompok perlakuan dosis II adalah 43,86 unit/ml. Kelompok kontrol negatif memiliki nilai SOD serum darah yang lebih tinggi dibandingkan dengan kelompok lain. Hal ini dikarenakan SOD pada kelompok kontrol negatif belum banyak terpakai dalam menangkal radikal bebas sehingga nilai SOD masih normal. Nilai SOD paling rendah adalah pada kelompok kontrol positif.

Pada kelopok perlakuan dosis I dan dosis II mengalami penurunan SOD yang relatif rendah. Pada dosis II tingkat penurunan lebih sedikit dibandingkan dosis I. Hal ini mengindikasikan bahwa dosis II mampu menangkal radikal lebih efektif dibandingkan dosis I walaupun keduanya tidak berbeda secara signifikan setelah dilakukan uji lanjut. Antioksidan pada effervescent dosis II mampu menangkal radikal bebas eksogen dari minyak jelantah dan dapat membantu peran SOD yang juga berperan sebagai antioksidan, sehingga penurunan nilai SOD paling sedikit dibandingkan kelompok kontrol positif dan kelompok perlakuan dosis I. Semakin tinggi dosis antioksidan yang diberikan, maka semakin besar nilai SOD (14). Artinya, antioksidan tersebut dapat membantu SOD dalam menetralisir radikal bebas sehingga lebih sedikit SOD yang digunakan untuk menangkal radikal bebas.

Produk oksidasi terakumulasi seperti MDA pada mitokondria dan hepar disertai kerusakan oksidatif akan mengarah pada kerusakan yang lebih progresif sehingga menyebabkan penurunan aktivitas enzim intraseluler seperti SOD, Glutathione Peroxidase (GPx) serta Catalase (CAT) sebagai antioksidan utama dalam tubuh. Kondisi ini akan mengakibatkan stress oksidatif dan timbulnya berbagai penyakit degeneratif (15).

Pada Gambar 1 menunjukkan bahwa kontrol positif mengalami kondisi stres oksidatif, ditunjukkan dengan banyaknya sel yang mengalami nekrosis (kematian). Ciriciri sel nekrosis ditunjukkan dengan perubahan inti sel yaitu dengan adanya fenomena piknosis dan karyolisis pada gambaran histopatologinya. Histomorfologi inti sel yang mengalami nekrosis terdiri dari satu atau lebih syarat-syarat yang digambarkan yaitu adanya piknosis, karioreksis, dan kariolisis. Bila sel mengalami nekrosis, biasanya inti sel yang mati tersebut akan menyusut, batasnya tidak teratur dan berwarna gelap. Proses ini

\section{DAFTAR PUSTAKA}

1. Qauliyah A. Mekanisme Kerja Beberapa Antioksidan. ( O n I i n e) M a r 2006 . http://astaqauliyah.com/blog/read/75/mekanismekerja-beberapa-antioksidan.html\#_ [diakses tanggal 3 Maret 2011]

2. Rechner AR and Kroner C. Anthocyanins and Colonic Metabolites of Dietary Polyphenols Inhibit Platelet Function. Thrombosis Research. 2005; 116(4): $327-$ 334.

3. Wang LS and Stoner GD. Anthocyanins and Their Role dinamakan piknosis. Kemungkinan lain, inti dapat hancur dan meninggalkan zat kromatin yang tersebar di dalam sel. Proses ini dinamakan karioreksis. Akhirnya pada beberapa keadaan ini yang mati kehilangan kemampuan untuk diwarnai dan menghilang begitu saja, proses ini disebut kariolisis (16).

Pada kelompok kontrol positif, pemberian minyak jelantah tidak diimbangi dengan penambahan asupan antioksidan, sehingga mengakibatkan kondisi stres oksidatif pada sel hepar. Pada umumnya cedera akibat radikal bebas dapat dikontrol oleh antioksidan intraseluler seperti SOD dan glutathione peroxidase. Bagaimanapun juga, cedera akibat radikal bebas dapat menjadi bencana apabila sistem antioksidan berjalan kurang baik. Kekurangan aktivitas antioksidan memberikan konsekuensi atas meningkatnya radikal bebas dan menyebabkan kondisi stres oksidatif sehingga menimbulkan cedera sel yang sangat hebat dan berujung nekrosis (16).

Pada kelompok kontrol negatif, gambaran histopatologi hepar menunjukkan ciri-ciri sel normal. Hal ini dikarenakan tidak adanya perlakuan pemberian radikal bebas ataupun pemberian sumber antioksidan. Pada kelompok perlakuan dosis I dan kelompok perlakuan dosis II sangat sedikit ditemukan sel yang mengalami nekrosis. Perbandingan antar dosis yang diberikan terlihat bahwa peningkatan dosis mampu menyebabkan perubahan morfologi sel hepar menjadi lebih baik, dimana pada dosis I sel hepar masih tampak adanya reversible injury sedangkan pada dosis II sel yang tampak cenderung normal. Peran SOD yaitu menangkal ROS untuk meredam reaksi lanjutan dari peroksidasi lipid sehingga memberi fungsi protektif terhadap kerusakan dan kematian sel (17).

Dapat disimpulkan peningkatan dosis effervescent rosela ungu yang diberikan mampu memberikan efek antioksidan yang signifikan dalam mencegah timbulnya kondisi stres oksidatif akibat minyak jelantah, pada serum darah dan sel hepar tikus. Hal ini ditunjukkan dengan peningkatan nilai SOD serum darah tikus serta perbaikan kondisi sel hepar tikus yang mengalami stres oksidatif melalui pengamatan pada gambaran histopatologi.

\section{UCAPAN TERIMA KASIH}

Kami ucapkan terimakasih kepada Direktorat Jendral Pendidikan Tinggi (DIKTI) Kementerian Pendidikan dan Kebudayaan Republik Indonesia yang telah memberikan bantuan pendanaan pada Program Kreatifitas Mahasiswa bidang Penelitian (PKM-P) pada tahun 2010.

in Cancer Prevention. Cancer Letters. 2008; 269(2): 281-290.

4. Vargaz FD and Lopez OP. Natural Colorants for Food and Nutraceutical Uses. Canada: CRC Press; 2003.

5. Ansel HC. Pengantar Bentuk Sediaan Farmasi. Edisi 4. Jakarta: UI Press; 2008.

6. Harler. Tea Manufacturing. London: Oxford University Press; 1997.

7. Zachary JF and McGavin MD. Pathologic Basic of Veterinary Disease. 4th Edition. Illinois: Mosby Elsevier Publishing Company; 2007. 
8. Giese S. Food Chemistry. 3rd edition. New York: Marcell Dekker, Inc.; 1996.

9. Saudah CN. Pembuatan Serbuk Effervescent Rosela (Hibiscus sabdariffa L.), Kajian Konsentrasi Maltodekstrin dan Suhu Pengeringan yang Berbeda Terhadap Sifat Fisik, Kimia, dan Organoleptik [Skripsi]. Universitas Brawijaya, Malang. 2008.

10. Golberg I and William R. Biotechnology and Food Ingredient. New York: Van Nostrand Reinhold; 1999.

11. Pokorny J, Yanishlieva N, and Gordon MH. Antioxidant in Food: Practical Application. Canada: CRC Press; 2001.

12. Sagita I. Kajian Keamanan Pangan Minyak Goreng Curah Akibat Penggorengan Berulang pada Pedagang Kaki Lima Penjual Lalapan Tempe, Ayam dan Lele Goreng [Skripsi]. Universitas Brawijaya, Malang. 2009

13. Ukeda H. Assay of Enzyme Superoxide Dismutase
(SOD). (Online) Jan. 2001. http://www. biomaxkorea. $\mathrm{com} /$ tech/tool/review/so.htm [diakses tanggal 23 Januari 2011].

14. Alamsyah A. Pengaruh Antioksidan pada Tempe Kedelai Terhadap Kadar Superoksida Dismutase (SOD) dan Malonaldehid (MDA) Serum Tikus Wistar Dipapar dengan Asap Rokok Sub Akut. [Skripsi]. Universitas Brawijaya, Malang. 2000.

15. Christina S. Efek Ekstrak Kacang Tunggak (Vigna unguiculata) terhadap Kadar Superoxide Dismutase (SOD) Serum Tikus Putih (Rattus norvegicus) Strain Wistar yang Telah Diovarektomi. [Skripsi]. Universitas Brawijaya, Malang. 2010.

16. Pierce SA and Wilson LM. Patofisiologi, Konsep Klinis Proses-proses Penyakit. Edisi 6. Jakarta: EGC Press; 2006; Jakarta.

17. Rieger C. Genistein. (Online) Mar. 2008. http://www.phytochemicals.info/phytochemicals/ge nistein.php [diakses tanggal 3 Maret 2011]. 